\title{
Fabrication of a hollow bulb prosthesis for the rehabilitation of an acquired total maxillectomy defect
}

\author{
C H Vamsi Krishna, ${ }^{1}$ Jaya Krishna Babu, ${ }^{1}$ Tanveer Fathima, ${ }^{2}$ G V K Reddy ${ }^{1}$
}

${ }^{1}$ Department of Prosthodontics, Sri Sai College of Dental Surgery, Vikarabad, Andhra Pradesh, India

${ }^{2}$ Department of Prosthodontics, Al Badar Dental College, Gulbarga, Karnataka, India

\section{Correspondence to} Dr C H Vamsi Krishna, chvk_guntur@yahoo.co.in

Accepted 7 March 2014

\section{CrossMark}

To cite: Vamsi Krishna $\mathrm{CH}_{\text {, }}$ Babu JK, Fathima T, et al. BMJ Case Rep Published online: [please include Day Month Yearl doi:10.1136/ bcr-2013-201400

\section{SUMMARY}

The prosthodontic rehabilitation of maxillary defects is a challenging and demanding task which requires careful pre-surgical and post-surgical planning. Maxillary defects can be congenital or acquired. Acquired defects include those following trauma or surgical treatment of benign or malignant neoplasms. A prosthodontist encounters problems such as absence of support, poor retention, and lack of prosthesis stability in treating these patients. The present case report describes a procedure to fabricate a definitive hollow bulb obturator prosthesis for the rehabilitation of a total maxillectomy defect.

\section{BACKGROUND}

Oral rehabilitation after maxillectomy presents diverse clinical and technical problems. A correctly designed obturator prosthesis helps to restore normal aesthetics, phonetics and function. The defects created after surgical excision of oral tumours vary depending on the size, location, and potential behaviour of the tumour. ${ }^{1}{ }^{2}$ An obturator prosthesis is used to restore masticatory function and improve speech, deglutition and cosmetics for patients with maxillary defects. ${ }^{3-6}$ Construction of a hollow bulb obturator reduces the weight of the prosthesis, making it more comfortable and efficient. Some authors have proposed different classification systems for maxillary defects, reference to which helps in planning treatment. ${ }^{7-9}$ The present case report describes a method for rehabilitating patients with total maxillectomy defects.

\section{CASE PRESENTATION}

A 31-year-old male patient presented with a large intraoral defect on the left side of the maxillary arch. On examination, facial asymmetry with defective speech was noted. Intra-oral examination revealed a

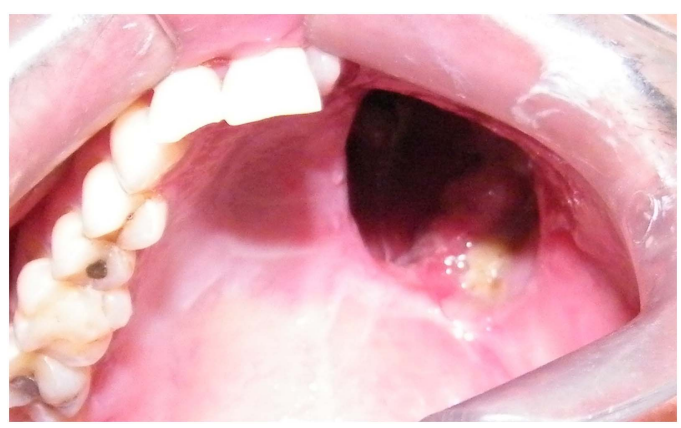

Figure 1 Intra-oral photograph showing the defect.

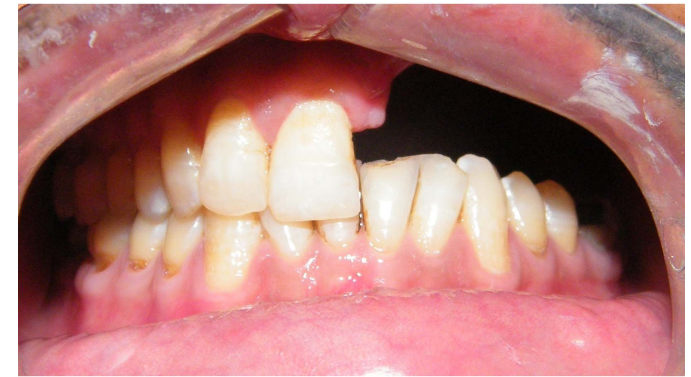

Figure 2 Maxillary and mandibular teeth in occlusion.

maxillary defect on the left side with oro-nasal and oro-antral communications (figure 1). The patient reported a medical history of squamous cell carcinoma of the maxillary arch which was surgically excised. Maxillary bone with alveoli and associated teeth on the left side had also been surgically excised. The patient reported difficulty in swallowing and regurgitation of fluids through the nasal cavity. A full complement of natural teeth was present on the right side of maxillary arch (figure 2).

\section{TREATMENT}

The patient was determined to have a class 1 defect according to the Armany classification system ${ }^{7}$ and it was decided to fit him with a definitive hollow bulb obturator prosthesis. Preliminary impressions were obtained using elastomeric putty (Aquasil, Densply) with a modified stock tray. A custom tray was fabricated on the preliminary cast and the

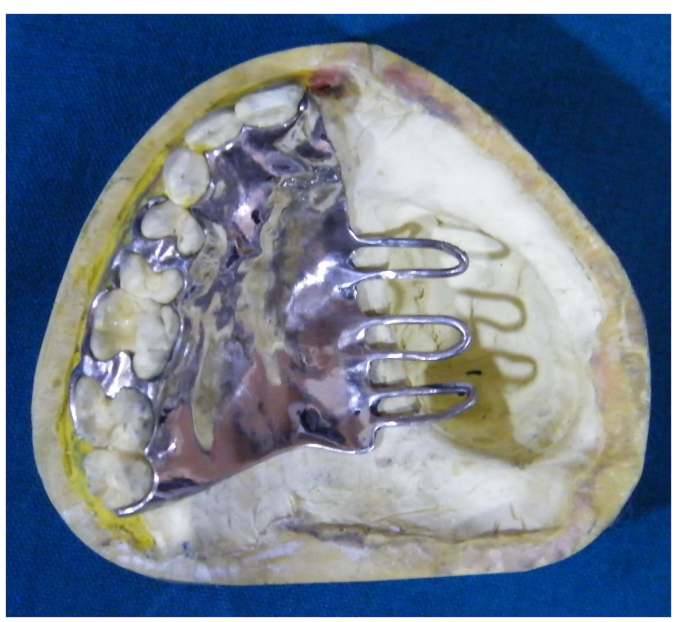

Figure 3 Partial denture framework. 


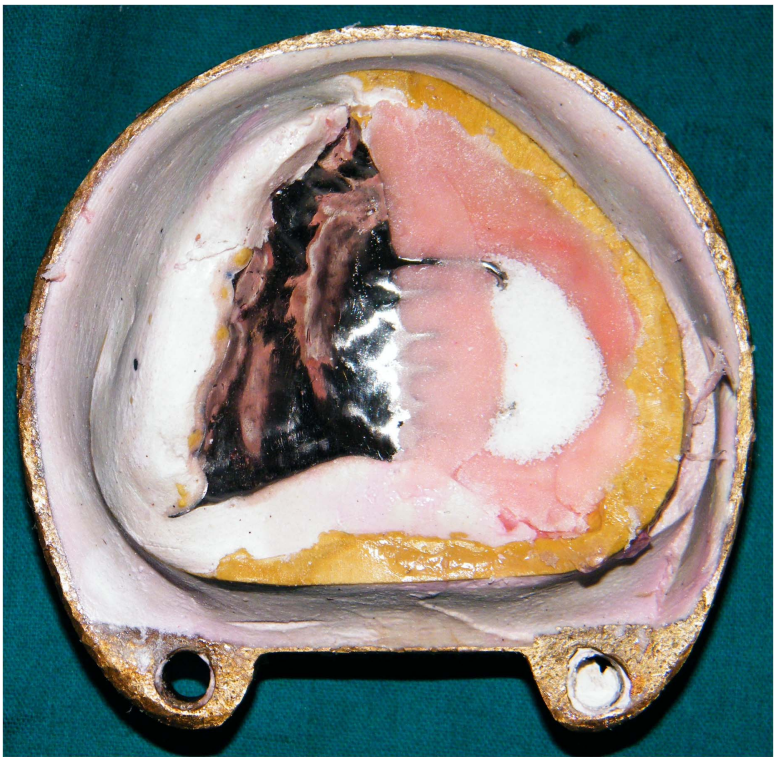

Figure 4 Filling the salt into the bulb portion of the resin during packing.

extent of the defect was recorded using an elasomeric putty material followed by border moulding. A final impression was obtained with a light-bodied polyvinyl siloxane material (Aquasil, Densply). After the master cast had been obtained, a cast partial framework was fabricated on the refractory model (figure 3). A jaw relation record was then obtained and trial denture fitting was carried out. The denture was invested in a denture-curing flask and acrylised to fabricate a hollow bulb obturator using the lost salt technique (figure 4). After processing, the salt was removed by injecting water and an elastomeric putty index was made over the prominent part of the bulb (figures 5 and 6). The bulb of the obturator was perforated to further reduce the thickness (figure 7). This step also significantly decreased the weight of the prosthesis as the thickness of the prosthetic bulb extending into the defect was reduced. The open bulb was closed using a thin sheet of wax (figure 8). Auto-polymerising resin was mixed and placed on the index and

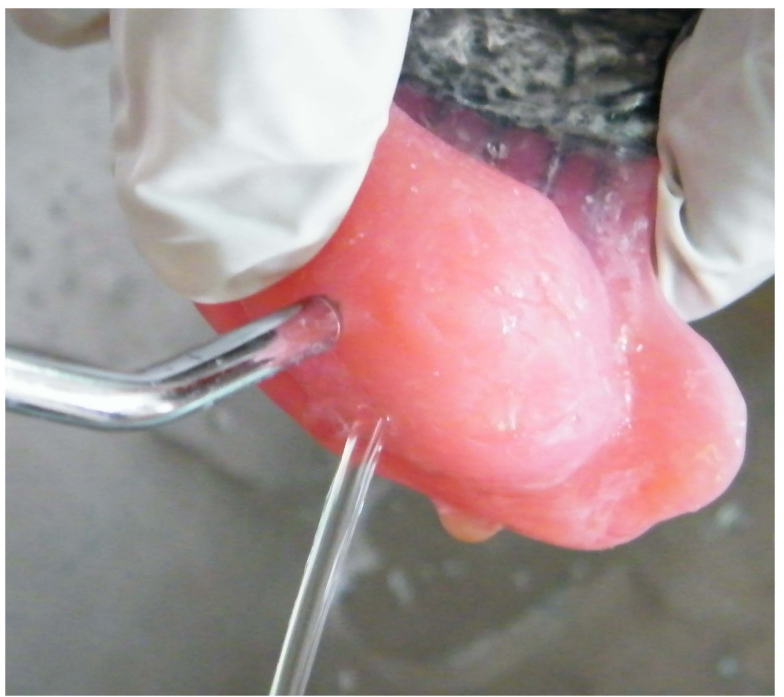

Figure 5 Removal of the salt after acrylisation.

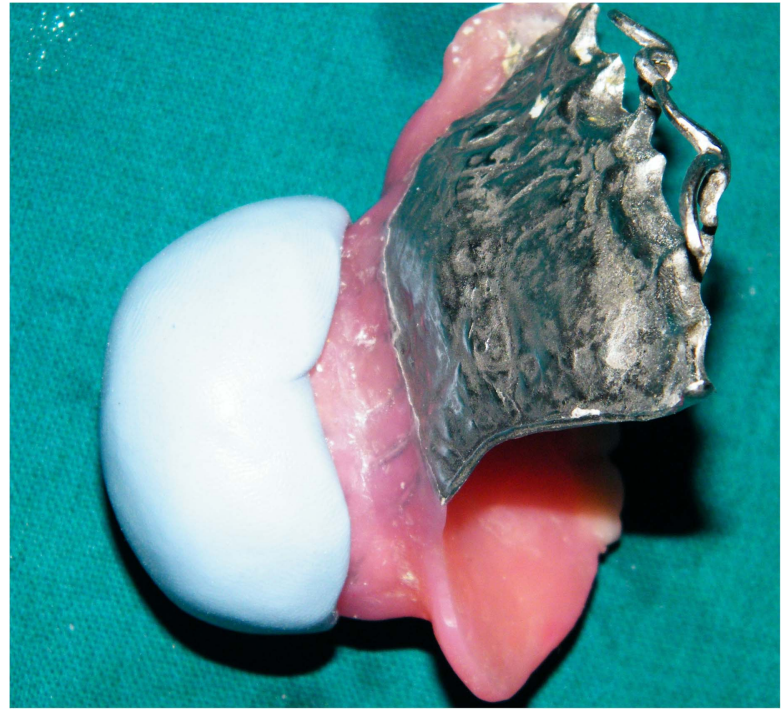

Figure 6 Elastomeric putty index made on the surface of the bulb.

approximated back on to the prosthesis. The wax helped to seal the open bulb and to prevent the acrylic flowing into the hollow cavity (figure 9). After the acrylic had set, the obturator was polished and delivered to the patient (figure 10).

\section{OUTCOME AND FOLLOW-UP}

A good prosthetic outcome was observed after the treatment and in follow-up appointments.

\section{DISCUSSION}

Obturator prostheses are commonly used for the rehabilitation of patients with maxillary defects. The bulb, or part of prosthesis extending into the defect, is usually hollow to reduce the weight of the prosthesis. Various methods have been described to fabricate hollow bulb obturators. ${ }^{10-16}$ Different materials, such as sugar, salt and ice, can be incorporated into the resin during the packing stage to produce a hollow bulb obturator, although the simplest method is to grind out the interior of the obturator bulb after acrylisation. Once the obturator is hollow, a

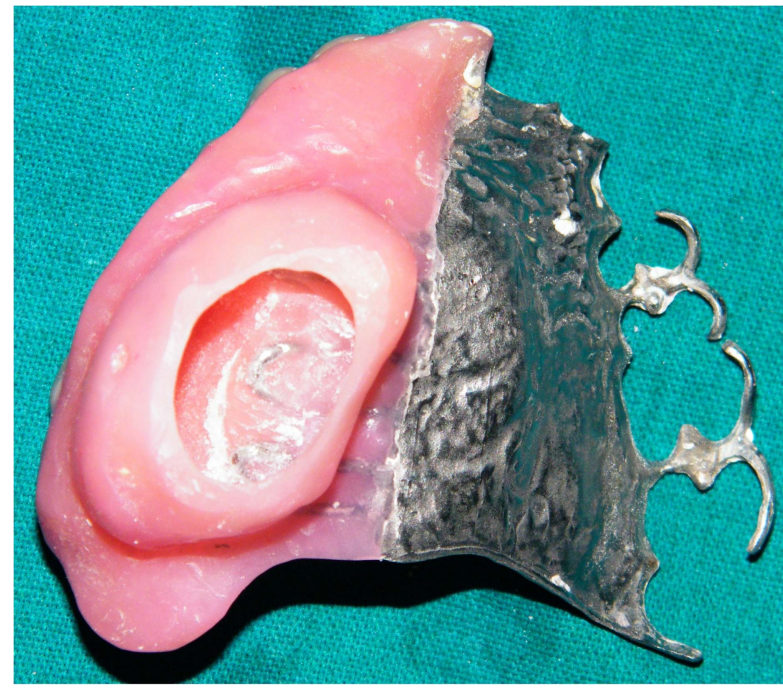

Figure 7 Hollow bulb after the removal of resin from the inner part of the bulb. 


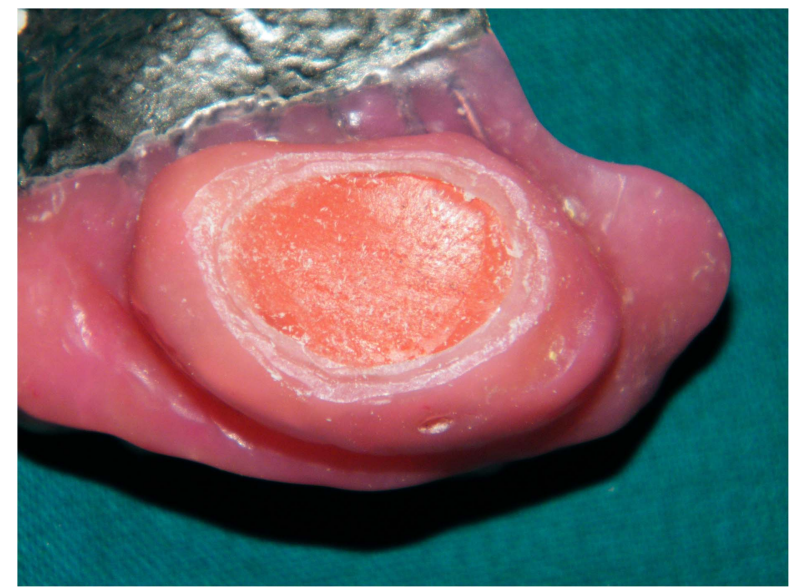

Figure 8 Opening closed with a thin wax sheet.

lid can be secured to the obturator to convert an open bulb into a closed one.

Different techniques have been advocated for making hollow bulb obturators. Oh and Roumanas ${ }^{13}$ suggested a double processing technique to optimise the thickness of the bulb. Habib and Driscoll ${ }^{14}$ suggested a method whereby a part of the bulb similar to a lid is removed and then joined back to the prosthesis after the bulb has been hollowed. Similarly, Asher et al ${ }^{15}$ proposed a quick and easy method to convert a solid bulb into a hollow bulb prosthesis. According to their technique, a plaster index was made on the bulb before the bulb was hollowed. The index with auto-polymerising resin was then approximated back onto the prosthesis to form a lid. However, in this technique the thickness of the lid may vary. A modification of this technique ensuring a thin lid is presented here. An index was made of elastomeric putty instead of plaster. Once the index had been made, the bulb was hollowed and the opening was closed with a thin layer of modelling wax, which prevented resin flowing into the bulb. Auto-polymerising resin was then mixed and placed on to the index, which was approximated back to the prosthesis. After fabrication of the lid, the prosthesis was finished and polished. Different attachment systems were used to join the pieces of obturator together. ${ }^{17} 18$

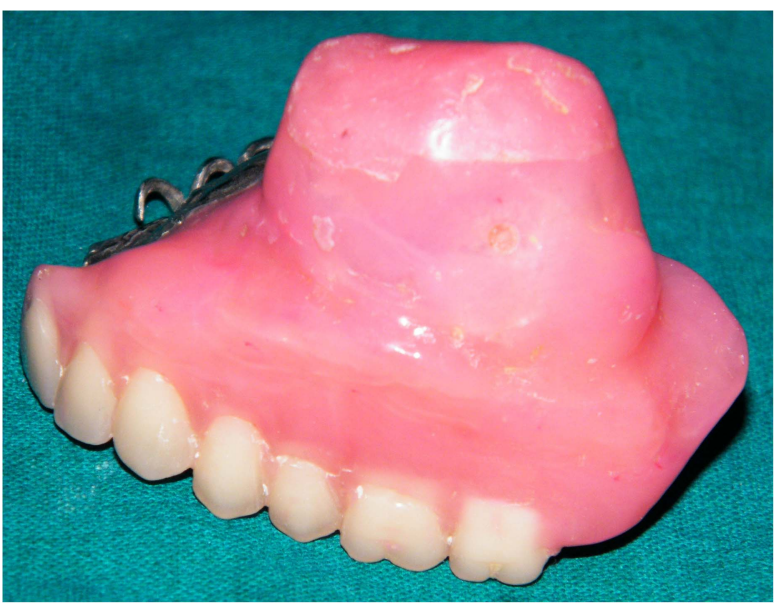

Figure 9 Final prosthesis.

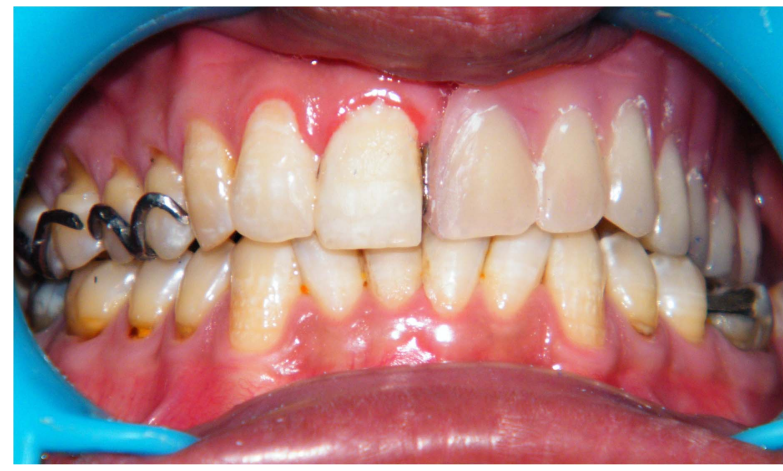

Figure 10 Post-insertion photograph.

\section{Learning points}

A closed hollow bulb obturator prosthesis is comfortable for patients because of its light weight and hygienic design.

- The present technique is a simple and quick procedure for converting a solid bulb prosthesis into a closed hollow bulb prosthesis.

- Proper designing of type of prosthesis improves prosthetic outcome of the patient.

\section{Competing interests None.}

Patient consent Obtained.

Provenance and peer review Not commissioned; externally peer reviewed.

\section{REFERENCES}

1 Curtis TA. Treatment planning for intraoral maxillofacial prosthetics for cancer patients. J Prosthet Dent 1967:18:70-6.

2 Lang BR, Bruce RA. Presurgical maxillectomy prosthesis. J Prosthet Dent 1967;17:613-19.

3 Taylor TD. Clinical maxillofacial prosthetics. Quintessence Publishing, 2000:85-102.

4 Chalian VA, Drane JB, Standish SM. Maxillofacial prosthetics. Multidisciplinary practice. Baltimore: Williams \& Wilkins, 1971:133-48.

5 Beumer J, Curtis TA, Firtell DN. Maxillofacial rehabilitation. St. Louis: Mosby, 1979:188-243.

6 Singh M, Bhushan A, Kumar $N$, et al. Obturator prosthesis for hemimaxillectomy patients. Natl J Maxillofac Surg 2013;4:117-20.

7 Aramany MA. Basic principles of obturator design for partially edentulous patients. Part I: classification. 1978. J Prosthet Dent 2001;86:559-61.

8 Okay DJ, Genden E, Buchbinder D, et al. Prosthodontic guidelines for surgical reconstruction of the maxilla: a classification system of defects. J Prosthet Dent 2001;86:352-63.

9 Spiro RH, Strong EW, Shah JP. Maxillectomy and its classification. Head Neck 1997;19:309-14

10 Didier M, Laccoureye 0 , Brasnu D, et al. New surgical obturator prosthesis for hemimaxillectomy patients. J Prosthet Dent 1993;69:520-3.

11 Wang RR, Hirsch RF. Refining hollow obturator base using light-activated resin. J Prosthet Dent 1997:78:327-9.

12 McAndrew KS, Rothenberger S, Minsley GE. 1997 Judson C. Hickey Scientific Writing Awards. An innovative investment method for the fabrication of a closed hollow obturator prosthesis. J Prosthet Dent 1998;80:129-32.

13 Oh WS, Roumanas ED. Optimization of maxillary obturator thickness using a double-processing technique. J Prosthodont 2008;17:60-3.

14 Habib BH, Driscoll CF. Fabrication of a closed hollow obturator. J Prosthet Dent 2004;91:383-5

15 Asher ES, Psillakis JJ, Piro JD, et al. Technique for quick conversion of an obturator into a hollow bulb. J Prosthet Dent. 2001:85:419-20.

16 Deogade SC, Mantri SS, Naitam D, et al. A direct investment method of closed two-piece hollow bulb obturator. Case Rep Dent 2013;2013:326530.

17 Gunasekar C, Nasser KS, Sabarigirinathan C, et al. Modified snap-on attachment with '0-ring' for two piece hollow bulb obturator. Indian J Dent Res 2013;24:507-10.

18 Elangovan S, Loibi E. Two-piece hollow bulb obturator. Indian J Dent Res 2011:22:486-8 
Copyright 2014 BMJ Publishing Group. All rights reserved. For permission to reuse any of this content visit http://group.bmj.com/group/rights-licensing/permissions.

BMJ Case Report Fellows may re-use this article for personal use and teaching without any further permission.

Become a Fellow of BMJ Case Reports today and you can:

- Submit as many cases as you like

- Enjoy fast sympathetic peer review and rapid publication of accepted articles

- Access all the published articles

- Re-use any of the published material for personal use and teaching without further permission

For information on Institutional Fellowships contact consortiasales@bmjgroup.com

Visit casereports.bmj.com for more articles like this and to become a Fellow 